\title{
Amino Acid-Responsive Crohn's Disease: A Case Study [Retraction]
}

Stein A, Hinz M, Uncini T. Clin Exp Gastroenterol. 2010;3:171-177.

The Editor-in-chief and Publisher of Clinical and Experimental Gastroenterology wish to retract the published article.

Following the conclusion of our investigation the decision has been made to retract the published article. The authors did not provide the requested IRB and consent to publish information relating to this study and it was determined the study did not meet the ethical publication requirements for research involving human subjects. These requirements are based on guidelines issued by the World Medical Association and the International Committee of Medical
Journal Editors. Additionally, the authors did not provide the study protocols, raw data and other study documents relating to this study as requested. Given our concerns about the standard of research ethics, competing interests and that the authors have not supplied the information we requested to verify and validate the reported findings, the editor has determined the article should be retracted.

Our decision-making was informed by our policy on publishing ethics and integrity and the COPE guidelines on retraction.

The retracted article will remain online to maintain the scholarly record, but it will be digitally watermarked on each page as "Retracted".

\section{Publish your work in this journal}

Clinical and Experimental Gastroenterology is an international, peerreviewed, open access, online journal publishing original research, reports, editorials, reviews and commentaries on all aspects of gastroenterology in the clinic and laboratory. This journal is indexed on American Chemical Society's Chemical Abstracts Service (CAS)
The manuscript management system is completely online and includes a very quick and fair peer-review system, which is all easy to use. Visit http://www.dovepress.com/testimonials.php to read real quotes from published authors. 